DOI: 10.17805/trudy.2017.6.6

\title{
СТОЛЫПИНСКОЕ ДЕЖАВЮ ГЕНЕРАЛА ВРАНГЕЛЯ
}

\author{
П. Ф. Алешкин \\ Журнал «Наша молодежь», г. Москва, \\ Ю. А. Васильев \\ Московский гуманитарный университет
}

Аннотация: В статье указывается, что последний Верховный правитель белого движения генерал П. Н. Врангель подвергал резкой критике просчеты А.В. Колчака и А.И. Деникина в отношении аграрной реформы. Врангель предпринял попытку решительного поворота в решении земельного вопроса с целью привлечения на свою сторону крестьянства, преимущественно средних и зажиточных слоев.

Программа Врангеля, походивщая на столыпинскую, была направлена на преодоление отживщего помещичьего землевладения и создание условий для развития капиталистических отношений в деревне. Утверждается, что одновременно земельная реформа Врангеля являлась симбиозом стольпинской реформы и преобразований Александра II.

Ключевые слова: Гражданская война; Россия; история России; власть; народ; крестьянство; Белое движение; П. Н. Врангель; крестьянский вопрос; аграрная политика

\section{GENERAL WRANGEL'S DEJA VU OF STOLYPIN \\ P. F. Aleshkin \\ Journal «Our Youth», Moscow, Yu. A. Vasiliev \\ Moscow University for the Humanities}

Abstract: The authors testify that the last Supreme Ruler of the White Movement, general P. N. Wrangel highly criticised the miscalculations of $A$. V. Kolchak and A. I. Denikin in relation to the agrarian reform. Wrangel attempted to make a decisive turn in the solution of the land issue in order to win over peasantry, predominantly from the middle and prosperous strata.

Wrangel's programme, similar to Stolypin's, was aimed at overcoming obsolete landed estates and creating conditions for the development of capitalist relations in the countryside. It is stated that Wrangel's land reform was simultaneously a symbiosis of the Stolypin reform and the reforms of Alexander II.

Keywords: Civil war; Russia; history of Russia; power; people; peasantry; White Movement; P. N. Wrangel; peasant issue; agrarian policy 
В проблематике Гражданской войны в России особый исследовательский интерес вызывает политика генерала П. Н. Врангеля в отношении крестьянского населения. Преемник генерала А. И. Деникина в должности Верховного правителя России (см.: Алешкин, Васильев, 2017) генерал П.Н. Врангель ${ }^{1}$ предпринял попытку привлечь на сторону белой Русской армии российское крестьянство. Для этого он предложил собственный вариант решения земельного вопроса, имевший «исключительное психологическое значение»: в рядах обеих противоборствующих сторон сражались мобилизованные крестьяне. Для опоры власти на широкие крестьянские массы нужен был закон о земле, отвечающий желаниям и чаяниям крестьянства. Врангелевский закон о земле декларировал решительный поворот в земельной политике южно-русской власти, которая стала искать опору в крестьянстве, преимущественно в средних и зажиточных его слоях.

Целью данной статьи является осмысление содержания аграрных преобразований последнего Верховного правителя белой России в контексте условий Гражданской войны. Этот сюжет ранее не был освещен в опубликованных работах авторов. Он был изложен лишь в диссертации П. Ф. Алешкина (Алешкин, 2012), научным консультантом которого являлся проф. Ю.А.Васильев. В диссертации крестьянский вопрос в Белом движении рассматривался в качестве одного из факторов крестьянского протестного движения (параграф 5.1). Представляется, что диссертационный текст, имеющий весьма ограниченное распространение для массового читателя, не выполняет просветительскую функцию, поэтому вниманию широкой аудитории предлагается материал, переработанный в форме статьи в электронном издании, доступном для любого читателя - как специалиста, так и любителя истории. К тому же документальный материал, извлеченный из оригинального печатного источника - второй части «Записок» П. Н. Врангеля (опубликованных в 1995 г. по инициативе П. Ф. Алешкина) в данной статье заявлен и рассматривается в ином ракурсе - обосновании причин, почему крестьянство не стало социальной основой Белого движения.

Главная задача аграрной реформы виделась Врангелю в том, чтобы «наибольшее количество земли могло бы быть использовано на правах

${ }^{1}$ Врангель Петр Николаевич (1878-1928) - генерал-лейтенант, барон, происходил из потомственных дворян Петербургской губернии, потомков обрусевших шведов. В августе 1918 г. вступил в Добровольческую армию генерала Деникина. Начальник 1-й конной дивизии, в ноябре был назначен командиром 1-го конного корпуса, с января 1919 г.- командующий Кавказской Долбровольческой армией, с 8 мая Кавказской армией, с 22 ноября по 21 декабря 1920 г. - Добровольческой армией. 22 марта 1920 г. ушедшим в отставку Деникиным был назначен главнокомандующим Вооруженными Силами на Юге России (с 28 апреля - Русская армия). В ноябре 1920 г. во главе остатков армии эвакуировался в Турцию. 
частной собственности теми, кто в эту землю вложил свой труд» (Врангель, 1995: 56). Крупное землевладение признавалось отжившим свой век, будущность России отдавалась крестьянину-собственнику. Врангель отдал приказ об образовании в Симферополе комиссии по разработке земельного вопроса под председательством Г. В. Глинки ${ }^{1}$. «Рководящие начала», предложенные Врангелем, включали следующие установки: вся пригодная к обработке земельная площадь должна быть полностью использована; землей должно владеть на правах установленной частной собственности возможно большее число лиц, способных вкладывать в нее свой труд; государство определялось в качестве посредника для расчетов между землевладельцами; все наделяемые землей землепашцы должны получить ее в законном порядке - в собственность за выкуп; создать для осуществления реформы на местах органы земского самоуправления и привлечь к участию в них самих крестьян (см.: Врангель, 1995: 56-58, 66, 72, 75). Наспех собранную комиссию Глинки составили представители различных политических взглядов - от консервативных до кадетских и правоэсеровских. Большая часть комиссии врангелевскую идею не разделяла, считая время для проведения земельной реформы неподходящим и рекомендовала отложить его до окончания войны. Первоначальный проект комиссии Глинки, в котором основные мероприятия реформы были приурочены к будущей весне, Врангелем был отвергнут.

20 мая 1920 г. в Севастополе было обнародовано воззвание Врангеля «к русским людям», в котором заявлялась цель: борьба за то, чтобы крестьянин, приобретая в собственность обрабатываемую им землю, занялся бы мирным трудом; чтобы русский народ сам выбрал бы себе хозяина. Приказ «правителя и главнокомандующего Вооруженными Силами на Юге России», подписанный в тот же день, 20 мая, призвал русский народ на помощь белой армии. Дух приказа содержался в лозунге: «Народу - земля и воля в устроении государства». Объявлялось о подписании закона о волостном земстве. На самом деле приказ Врангеля о волостном земстве был подписан позднее - 15 июля 1920 г. Утвержденное 25 мая Временное положение о земельных учреждениях (приложение к Приказу о земле) лишь предусматривало передачу волостным земствам, когда они будут созданы, функции волостных земельных советов. Объявлялось также о восстановлении земских учреждений в занимаемых армией областях; о передаче казенной и частновладельческой земли сельскохозяйственного пользования распо-

\footnotetext{
${ }^{1}$ Глинка Григорий Вячеславович (1862-1934) - в 1908-1915 гг. - начальник Переселенческого управления, товарищ министра земледелия, тайный советник, активно проводил аграрную реформу П. А. Столыпина, с 1915г. - главноуполномоченный по снабжению армии продовольствием, с 1916 г. - сенатор. С июня 1920 г. - начальник управления земледелия и землеустройства в правительстве Врангеля.
} 
ряжением самих волостных земств обрабатывающим ее хозяевам. Как и в воззвании, провозглашалось: «Земле - волею народа поставленный Хозяин». Обращение было обнародовано 25 мая - ко времени издания приказа о земле (Врангель, 1995: 99, 118). С термином «хозяин» произошел казус: появилась трактовка с намеком на личные претензии главкома. Врангелю пришлось опровергать слухи по данному поводу и давать разъяснения, что под этим определением он подразумевал русский народ и его подлинных представителей, которые должны решить будущую судьбу России. Однако данное объяснение оказалось неубедительно: стало очевидным, что амбициозный и честолюбивый боевой генерал, монархические симпатии которого были хорошо известны, невольно проговорился.

В качестве председателя врангелевского «Правительства Юга России» был привлечен прибывший в мае из Парижа А. В. Кривошеин ${ }^{1}$, ближайший помощник Столыпина в проведении аграрной реформы. Кривошеин и Глинка, основные творцы врангелевской реформы, на основе собственного опыта создания слоя «столыпинских крестьян» изначально ориентировались на зажиточное крестьянство («трудовое, но крепкое земле крестьянство»): организовать, сплотить и привлечь крепких сельских хозяев к охране государственности. По характеристике члена комиссии по разработке земельной реформы В. А. Оболенского, Кривошеин был «человек, искренне и горячо любящий Россию» (Оболенский, 1991: 380-381). Это был «человек большого ума, лучше многих понимавший всю глубину происходивших в русской жизни изменений и ясно представлявший себе, что возврата к прошлому нет. Но ... он все-таки был плоть от плоти бюрократии старого режима. Головой он понимал, что нужны новые методы методы управления, в смысле упрощения административного аппарата, предоставления больших прав самоуправлениям, демократизации отношения. власти к населению и т. п. Но долгая бюрократическая служба создала в нем известные привычки и связи с определенным кругом людей» (там же: 381).

Врангель особо подчеркивал важность психологического воздействия на крестьянские массы, чтобы вырвать из рук красных главное орудие пропаганды против белой армии и белого движения: цель белых - восстановление помещичьих прав на землю и месть за их нарушение (Врангель, 1995: 75). Таким образом, повторялись установки столыпинской реформы,

\footnotetext{
${ }^{1}$ Кривошеин Александр Васильевич (1857-1921) - окончил юридический факультет Петербургского университета. С 1896 г. - помощник начальника, с 1902 г. - начальник Переселенческого управления. С 1908 г. по 1915 г. - министр земледелия, член Государственного совета и Совета министров, статс-секретарь. С октября 1918 г. по 1920 г. - товарищ председателя монархо-октябристского «Совета государственного объединения России». С ноября 1919 г. - начальник управления снабжения ВСЮР, с 6 июня 1920 г. - помощник главкома Русской армии генерала Врангеля по гражданской части, председатель «Правительства Юга России».
} 
направленные на преодоление отжившего помещичьего землевладения и создание условий для развития капиталистических по содержанию отношений в деревне.

Кривошеин настоял на придании, по его оценке, несовершенному закону, созданному в спешном порядке в условиях Гражданской войны, особой формы Приказа о земле, а посреднические земельные комиссии посоветовал назвать земельными советами. 25 мая 1920 г. был обнародован Приказ о земле и приложений к нему - Правил о передаче распоряжением правительства казенных государственных, земельного банка и частновладельческих земель сельскохозяйственного пользования в собственность обрабатывающих землю хозяев, Временного положения о земельных учреждениях. Правительственное сообщение по земельному вопросу разъясняло условия и причины издания земельного закона, его содержание и значение. Придавая земельному вопросу «исключительное значение для войск и населения», Врангель решил приурочить обнародование Приказа о земле к началу наступления войск. Он требовал принять меры к широкому ознакомлению крестьянства с Приказом о земле. Оценка приказа выражалась в следующих словах главкома: «Армия должна нести крестьянам землю на штыках - вот психологическое значение приказа» (Врангель, 1995: 172).

Амбиции правителя государством (в реальности - осколком бывшей Российской империи) подвигли Врангеля придать указанным законам легитимный характер. С этой целью Приказ о земле, Правила и Временное положение были обнародованы указом так называемого Правительствующего Сената - по сути, декоративного органа, заседавшего в то время в Ялте. Отметим, что торжественное открытие Правительствующего сената в Белом движении было проведено Верховным правителем Колчаком 29 января 1919 г. в зале судебных заседаний Омской судебной палаты. В речи на открытии сената Колчак заявил, что отныне, с восстановлением Правительствующего сената, «идея правового государства торжествует в освобожденной (от большевиков. - П. А., Ю. В.) стране» (Процесс над колчаковскими министрами ..., 2003: 608).

В Указе Сената говорилось: «Приказ правителя, облеченного всею полнотою власти, передает землю трудящимся хозяевам в вечную наследственную собственность, но не даром, а за выплату государству стоимости ее для расчетов с собственниками отчуждаемых земель. Такой путь перехода, распределения и укрепления земельных угодий отвечает правовым понятиям народа и соответствует историческому развитию земельного законодательства Верховной властью. Отныне в деревне должен установиться твердый земельный порядок и хозяйственная обеспеченность жизни трудящихся на земле, а самый закон будет осуществляться при ближайшем участии сельских хозяев, под высшим контролем правителя и главнокомандующего. 
Закон земельный направлен к общему благу государства, и на нем будет строиться экономическая мощь России. Споры, неудовольствия, раздоры вокруг земельного вопроса должны смолкнуть. Каждый верный сын нашей многострадальной Родины не из-за страха, а по долгу совести обязан отдать свои силы и знания и поступиться своими личными интересами, всемерно помогая правителю и главнокомандующему в скорейшем и наилучшем осуществлении закона о земле» (Врангель, 1995: 77).

Основные положения текста Приказа о земле сводились к следующему. Пахотные, сенокосные и выпасные угодья казенных имений и Государственного земельного банка и все излишки частновладельческих имений, превосходящих установленные размеры неприкосновенно сохраняемого за каждым хозяином владения, передавались трудящимся на земле хозяевам. Размеры участков, сохраняемых за собственниками, определялись для каждой волости местными земельными советами, но подлежали утверждению высшей правительственной властью. Исключение делалось для имений (в которых советскими властями были созданы совхозы), а также для культурных и промышленных хозяйств, имеющих государственное или краевое значение. Имения переходили во временное распоряжение правительства, которое могло передаваться в пользование казенным учреждениям или местному волостному земству, с обязательством сохранения в них примерного хозяйствования. В имениях подлежали передаче сельским хозяевам арендный фонд, а также все угодья, которые признавались излишними для имений как хозяйственных единиц. В имениях, на базе которых Советская власть организовала коммуны, последние подлежали немедленной ликвидации, после выделения участков для собственников они поступали в распоряжение волостных земельных советов. Последние учреждали в бывших имениях особые управления или передавали земли новым сельским хозяевам. Усадебная земля, передаваемая хозяевам и арендаторам вместе с усадебной недвижимостью, объявлялась неприкосновенной и не подлежащей отчуждению.

Казенные леса сохранялись в распоряжении казны, а частновладельческие поступали в распоряжение лесных правительственных управлений. Местное население имело право получать из частновладельческих лесов топливо и строительные материалы по мере действительной потребности в них, проводить разработку леса с целью увеличения в необходимых случаях сельскохозяйственной площади за счет лесных площадей.

Часть земельных угодий не подлежала отчуждению и сохранялась в неприкосновенности за их собственниками: надельные участки; земли, приобретенные при содействии Крестьянского банка по установленным нормам; земли, выделенные на хутора и отруба по землеустроительным правилам; земли, отведенные в надел для церквей и монастырей; участки, принадлежащие сельскохозяйственным опытным, учебным и ученым 
учреждениям; земли, предназначенные для культурно-просветительных поселков или для поселения на них воинов белой армии; усадебные, огородные земли, а также занятые искусственными насаждениями, поливными посевами и ценными культурами или садами, вне зависимости от принадлежности и размера; под мельницами, фабриками, заводами и другими постройками промышленного характера в размере, необходимом для их работы. Захваченные крестьянами земли подлежали законному возврату прежним владельцам. Приказ о земле был дополнен позднее положениями, изложенными в приказах Врангеля от 2 и 3 октября 1920 г.

Земельная реформа декларировала идею укрепления права бессословной частной земельной собственности. Для реализации данной идеи допускалось изменение собственников. Общегосударственные интересы объявлялись приоритетными в отношении права частной собственности граждан. Преобразуемый земельный строй ориентировался на укрепление связи землевладельца-хозяина с его землей: полное право собственника владеть и пользоваться и распоряжаться землей, иметь право на обособленное выделение своего участка (Врангель, 1995: 77-80).

Врангелевская реформа во многих своих положениях походила на столыпинскую. Однако, в отличие от Столыпина, отменившего выкупные платежи, Врангель сделал выкуп одной из ключевых основ своей земельной реформы: его государство нуждалось в материальных средствах, которые, по задумке организаторов, можно было получить за счет реформы. Основные поступления предполагалось получить в виде зерна, которое можно было отправить судами на экспорт в обмен на валюту. Армия и население Крыма также нуждались в обеспечении продовольствием и обмундированием. Врангель неоднократно подчеркивал, что зерно - единственный источник вывоза за рубеж и получения валюты для содержания и снабжения армии (там же: 245, 284).

Приказ о земле установил: все земли, подлежащие передаче хозяевам, укрепляются за ними в полную собственность, но не безвозмездно, а при условии выплаты государству их стоимости в различных формах. Право собственности на недра земли сохранялось за прежними владельцами, впредь до разрешения данного вопроса общероссийской государственной властью. Нетрудно догадаться, что прежним собственником недр являлось государство.

Отказ от нормативных ограничений сверху объяснялся возможностью сохранения на местах различных размеров хозяйств, если по местным условиям и по желанию местных жителей подобное распределение земель будет отвечать интересам земского мира и эффективности хозяйственного строя. Не требовалось ограничивать отдельный отрубной участок каждому хозяину, за которым закреплялась земля - считалось, что это потребует 
огромного количества землемеров и замедлит реализацию реформы (таким образом власть стремилась максимально сократить расходы на проведение реформы - средств у Врангеля не хватало). Поэтому предлагалось общее правило: производить немедленный отвод земли группам хозяев, откладывая окончательное землеустройство на последующее время. При этом оговаривалось, что земля должна отводиться непременно в личную, а не общую или общинную собственность: в одной общей площади участка для группы хозяев должно определяться, сколько земли принадлежит каждому хозяину (его доля), с правом производить выделение. Немедленное выделение отрубных участков отдельным хозяевам признавалось в тех случаях, когда это возможно по техническим условиям или необходимо в силу особых причин. Участки требовалось отводить с соблюдением основных правил землеустройства: владельцу - ближе к его усадьбе, а отдельным группам хозяев так, чтобы их участки не были чересполосны с другими отведенными участками и не препятствовали бы землеустройству на остальных землях имения, еще не распределенных между хозяевами.

Право выбора новых хозяев - собственников земли, определение предельного размера закрепляемых участков предоставлялось уездным земельным советам. Состав последних должен был формироваться из местных крестьян-хозяев - «хозяйственного элемента крестьянства... сообразно местным же потребностям хозяйственной жизни». Приказ о земле дал на этот общие указания, подлежащие обязательному исполнению: определение требований, которым должны соответствовать хозяева при укреплении за ними земель (подданство, несудимость, личный труд на земле, технические познания в земледелии, аренда земли, проживание в имении и т. п.); категорический запрет на укрепление земли за дезертирами и уклоняющимися от воинской повинности; преимущественное право на укрепление участков для хозяев, имевших на них собственную усадебную недвижимость и хозяйство или использовавших землю в форме аренды; земли в каждой волости предоставлялись в первую очередь для постоянных жителей волости (по признаку постоянного проживания и ведения на них хозяйства, а не формальной приписки к волости), из числа фактических хозяев-земледельцев. Данное требование лишало права на землю целую группу сельских жителей - так называемых иногородних на казачьих землях.

Лишь после обеспечения постоянных хозяев свободные остатки земли могли быть использованы для пришлого земледельческого населения; волостные земельные советы обязывались с особым вниманием учитывать права на землю воинов белой армии, защищать их интересы и предоставлять им и их семьям преимущественное право на укрепление земли; установление предельного размера фактического землевладения, закре- 
пляемого за отдельными хозяевами. Фактическое владение хозяев, превышающее размер установленных для данной местности норм, не подлежало сокращению. Приведенные обязательные для местных земельных советов «руководящие указания» врангелевской власти не оставляли иллюзий по поводу того, в чьих интересах проводилась земельная реформа и кому она была поручена на местах. Создавая опору в лице крепких сельских хозяев, Врангель стремился не обидеть прежних землевладельцев. В первоначальном проекте комиссии Глинки устанавливалось право землевладельцев оставить себе в качестве неотчуждаемой земли участок до 200 десятин. Неслучайно, вероятно, что разрешение ряда важнейших вопросов для основной массы земледельческого населения было отнесено к частным - о них просто забыли из-за «спешности». К числу таких вопросов относилось, например, определение размеров и порядка взимания аренды и «скопщины» (арендная плата собственнику зерном с «копны») за урожай 1920 г. на мелких земельных участках.

Приказ о земле отвергал идею всеобщего наделения землей, не допускалась бесплатная раздача земли. Никаких обещаний не давалось об обеспечении землей всех желающих, о возможности сделать земельными собственниками и сельскими хозяевами деревенскую бедноту. Отвергалась мысль об уравнительном землепользовании в масштабе всероссийского земельного передела - все сводилось к упорядочению землепользования местной властью в пределах своей волости. Местный характер землеустройства противопоставлялся широким планам «неосуществимого общего передела земель всего государства между всеми, для чего потребовалось бы принудительное расселение и переселение широких масс земледельческого населения с севера на юг и с запада на восток на пространстве шестой части вселенной». Таким образом, приказ Врангеля подчеркнуто высмеивал политику большевиков, основанную на широких и заведомо невыполнимых обещаниях всему трудовому народу.

Врангель стремился в выгодном для себя свете противопоставить собственную программу от «всяких программ советского землеустройства», подчеркивая ее «существенное отличие» от последних - новые собственники обязаны вносить в казну выкуп на установленных законных основаниях. Выкуп определялся следующими требованиями: полная оплата государству стоимости каждой десятины полезной земли, без различия - пахотной, сенокосной или выпасной; оплатой признавалась сдача в государственный запас хлеба в зерне, преобладающего в местности посева (ржи или пшеницы), в количестве пятикратного за последние десять лет урожая этого хлеба с казенной десятины. Средний ежегодный урожай с десятины умножался на пять. Произведение, выраженное в пудах, являлось стоимостью выкупа.

Размеры среднего за последние десять лет урожая с десятины для 
каждого уезда или волости выяснялись уездными земельными советами и представлялись на утверждение совета при главнокомандующем; количество хлеба, определенное в оплату отчуждаемых участков, должно было вноситься новыми собственниками в течение 25 лет ежегодно равными частями, составляющими на каждую десятину одну пятую часть среднего урожая; плательщику предоставлялось право досрочно произвести полную оплату стоимости всего или части закрепленного за ним участка земли взносом хлеба или его денежной стоимости по рыночным ценам; по ходатайствам плательщиков правительству предоставлялось право заменять годовые хлебные платежи деньгами по рыночной стоимости хлеба к сроку платежа (там же: 80-83). Стремление получить дивиденды от проведения реформы, одновременно также рассчитаться с прежними собственниками земли за счет выкупных платежей и удовлетворить их требования, напоминает механизм организации александровской земельной реформы 1861 г. Реформа Врангеля-Кривошеина-Глинки являла по своему содержанию симбиоз столыпинской реформы и реформы Александра II.

В сравнении с главной для крестьянства опасностью - возможной реставрацией крепостнических порядков политика военного коммунизма Советской власти, недовольство и сопротивление которой выражалось российским крестьянством в активных и пассивных формах протеста (см.: Алешкин, Васильев, 2010, 2012), воспринималась как «меньшее зло». К тому же аграрные приказы и мероприятия Белой власти, ориентированные, по модели столыпинской аграрной реформы, на зажиточного крестьянина, не могли удовлетворить интересы «осередняченной» после 1917 г. российской деревни.

\section{СПИСОК ЛИТЕРАТУРЫ}

Алешкин, П. Ф. (2012) Крестьянское протестное движение в России в условиях политики военного коммунизма и ее последствий (1918-1922 гг.) : дисс. ... д-ра ист. наук. М., 2012. С. 471-485.

Алешкин П. Ф., Васильев Ю. А. (2017) Коллизии аграрной политики генерала Деникина [Электронный ресурс] // Научные труды Московского гуманитарного университета. № 5. URL: http://journals.mosgu.ru/trudy/article/ view/568 (дата обращения: 04.11.2017). DOI: 10.17805/trudy.2017.5.6

Алешкин, П. Ф., Васильев, Ю. А. (2010) Крестьянская война в России в условиях политики военного коммунизма и ее последствий (1918-1922 гг.). М. : Голос-Пресс. 576 с.

Алешкин, П. Ф., Васильев, Ю. А. (2012) Крестьянские восстания в России в 1918-1922 гг. От махновщины до антоновщины. М. : Вече. 400 с.

Врангель, П.Н. (1995) Записки (ноябрь 1916 г. - ноябрь 1920 г.). Часть II // Белое дело: Избранные произведения : в 16 книгах. М. : Голос. Кн. 5. Послед- 
ний главком. 350 с.

Оболенский, В. А. (1991) Крым при Врангеле // Революция и гражданская война в описаниях белогвардейцев: в 6 т. / отв. ред. С. А. Алексеев. М. : Отечество. Т. 5.456 с. С. 350-378.

Процесс над колчаковскими министрами. Май 1920 г. (2003). М. : Международный фонд «Демократия» : Новый хронограф. 669 с.

Дата поступления: 11.11.2017 2.

Алешкин Петр Федорович - доктор исторических наук, главный редактор общероссийского журнала «Наша молодежь», член Русского интеллектуального клуба, член Союза писателей России. Адрес: 127486, Россия, г. Москва, Коровинское шоссе, оф. 6. Тел.: +7 (495) 625-44-61. Эл. адрес: aleshkin@list.ru

Васильев Юрий Альбертович - доктор исторических наук, профессор, профессор кафедры истории и регионоведения Московского гуманитарного университета. Адрес: 111395, Россия, г. Москва, ул. Юности, д. 5. Тел.: +7 (499) 374-55-81. Эл. адрес: historymosgy@mail.ru

Aleshkin Peter Fedorovich, Doctor of History, editor in chief of the Russian Journal « Our youth », a member of the Russian Intellectual Club, a member of the Writers Union of Russia. Postal address: 127486, Russia, Moscow, Korovinskoye highway, of. 6.. Tel.: +7 (495) 625-44-61.E-mail: aleshkin@list.ru

Vasiliev Yuriy Albertovich, Doctor of History, a Professor of the Department of History and Regional Studies of Moscow University for the Humanities. Postal address: 111395, Russia, Moscow, ul. Youth, 5. Tel.: +7 (499) 374-55-81. E-mail: historymosgy@mail.ru

\section{Для цитирования:}

Алешкин П. Ф., Васильев Ю. А. Столыпинское дежавю генерала Врангеля [Электронный ресурс] // Научные труды Московского гуманитарного университета. 2017. № 6. URL: http://journals.mosgu.ru/trudy/article/view/622 (дата обращения: дд.мм.гг.). DOI: 10.17805/trudy.2017.6.6 